\title{
Effect of egg size and lines on hatching performance of chicks from broiler breeders under selection
}

\author{
Olutunmogun, A. K., Umar, A. U., Adejoh-Ubani, E. O., Nwagu, B. I., Adeyinka, I. A. \\ and Muhammad, S. M.

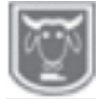 \\ National Animal Production Research Institute (NAPRI), \\ Ahmadu Bello University, Shika-Zaria, Kaduna State, Nigeria \\ Abstract \\ Corresponding author: Olutunmogunkayode@yahoo.com
}

The study was conducted with the objective of evaluating the effect of egg size (small, medium and large) and lines on egg and hatch weight, fertility, hatchability, embryonic mortality and infertile eggs of broiler breeders under selection. A total of 120 broiler chicks were hatched from three different egg sizes (40 chicks per egg size as indicated) from breeder parents at 40 weeks of age. The broiler breeders were mated in a ratio of 1:6. Data obtained were subjected to analysis of variance in a complete randomized design. The result showed that significant $(p<0.05)$ egg weight loss in incubator were recorded with the large egg size group having the minimum loss of $10.85 \%$. The hatch weight was significant $(p<0.05)$ and increased from the small to the large $(36.24,36.73$ and 40.22g) egg size group. Line had significant effect $(p<0.05)$ only on the medium egg size: egg weight (sire $=57.50 \mathrm{~g}$; dam $=$ $55.00 \mathrm{~g})$ and hatch weights (sire $=39.71 \mathrm{~g}$; dam $=36.10 \mathrm{~g})$. The fertility $(94.02,93.01$ and $78.01 \%)$, hatchability (87.42, 88.20 and $62.41 \%)$ and embryonic mortality $(6.58,9.80$ and $15.6 \%)$ had significant $(p<0.05)$ differences with the small egg size group performing better excluding the average egg weight, which was then followed closely by medium egg size group. It can be concluded that for higher hatch weight target, the large egg size should be selected but for the purpose of better fertility and hatchability, the medium and small egg sizes should be selected.

Keywords: Egg size, egg weight loss, fertility, hatchability.

\section{Introduction}

Poultry production has been reported to be the main source of household nutrition and income in the developing countries with most of the species being exotic (Javid et al., 2016). The production of poultry is practiced in Nigeria at all levels which ranges from subsistence to large scale commercial operations. Usually, the commercial operations rely on the exotic chicken breeds both for egg and meat type chickens. With this sort of operations at present, studies have nonetheless demonstrated conflicting evidence indicating that performance in broiler chickens in terms of hatchability and chickhatch weight may be closely related to the weight of the eggs (Wilson, 1991; Uluocak et al., 1995; Kalita, 1994; Abiola, 1999; Donald et al., 2002; Rashid et al., 2005; King'ori et al., 2007). Thus, the egg weight and chick weight at hatching are positively related (Khurshid et al., 2003). The time spent by broilers on the farm may be decreasing as selection for fast growth is required. The embryo has been found to still require 21 day incubation period, which translates into a greater percentage of the life of the broiler chicken being spent in the incubator. The size of the embryo before and at hatching can be altered by the weight of the egg and the incubation environment (Wilson, 1991). Furthermore, the performance potentiality of the chicken depends on egg quality. Egg quality is an important component for embryogenesis as 
well as for a 1day-old chick quality and growth. In hatchery management, the judgment of the quality of a day-old chick is usually based on qualitative aspects, such as abnormalities and contamination. Deeming (1995), observed that day-old chick quality can be related to several factors, such as incubator quality, incubation environment and egg characteristics among many others. The report of Tufft and Jesen (1991) revealed that the effect of the egg weight on body weight at market age is independent of the age of the breeders from which the eggs originated. Reports have shown that the broiler industry is running at commercial level and limited information exists on the effect of the hatching egg size, strains and breeder age on hatching performance. Egbeyale et al. (2011) observed the effect of breeder age to be largely associated with egg weight. King'ori (2011) suggested that chick weight, fertility and hatchability are interrelated heritable traits that vary among breeds, variety or individuals in a breed. Therefore, due to paucity of information on broiler parent stock under selection, it becomes very important to understand the effect of egg size and lines on hatching performance of chicks from broilers under selection as a sole objective of the study.

\section{Materials and methods \\ Experimental site}

The experiment was conducted at the Research Unit of the Poultry Research Programme of National Animal Production Research Institute, Shika-Zaria. Shika lies between latitude $11^{\circ} 12^{\prime} 42^{\prime \prime} \mathrm{N}$ and longitude $7^{\circ} 33^{\prime} 14^{\prime \prime} \mathrm{E}$ and altitude of $640 \mathrm{~m}$ above sea level (Ovimaps, 2014). The temperature of Shika ranges between 14.5 $39.5^{\circ} \mathrm{C}$ with a humidity range of $21-72 \%$ occurring during the early dry and wet season respectively. Detailed description of Shika climate has been given elsewhere by
Kabir et al. (2006).

\section{Experimental birds and management}

One hundred and fifty hatching eggs of different egg size were obtained from two lines of broiler parent stock under selection (sire and dam lines). Seventy five hatching eggs were collected from each line. The parent stock from which fertile eggs were obtained was 40 weeks of age. The birds were in a mating ratio scheme of one male to six females (1:6). The egg sizes from each line were weighed using a Camry digital sensitive weighing scale to one decimal place.

The eggs were then classified into three groups of small $(>41.0 \mathrm{~g}-51.0 \mathrm{~g})$, medium $(52.0 \mathrm{~g}-61.0 \mathrm{~g})$ and large $(62.0 \mathrm{~g}-<71.0 \mathrm{~g})$. Each egg group had 50 eggs. After setting in the incubator, at the $18^{\text {th }}$ day fertile eggs were sorted and weight loss was take in percent of the initial egg weight.

After hatching in individual trays, 120 dayold chicks were obtained from a Buckeye incubator; 20 chicks from each of the egg size were collected with a sum total of 60 chicks per line. The hatched chicks were then weighted and wing tagged so as to maintain a pedigree record of the birds. The chicks were intensively managed on deep liter system, medication and vaccinations were administered as at when due and feed and water was provided ad libitum.

Data collection

Data were collected for egg weight for the three egg sizes, percent weight loss, fertility, hatchability, embryonic mortality and infertile eggs were estimated as follows:

$\%$ infertile $=$

Total number of infertile eggs $x 100$

Total number of eggs set

$\%$ fertile $=100-\%$ infertile 


\section{Olutunmogun, Umar, Adejoh-Ubani, Nwagu, Adeyinka and Muhammad}

$\%$ hatchability $=$

Total number of hatched egg x 100

Total number of fertile eggs

The mathematical model is as expressed below:

$\mathrm{Y}_{\mathrm{ijk}}=\mu+\mathrm{L}_{\mathrm{i}}+\mathrm{S}_{\mathrm{j}}+\mathrm{e}_{\mathrm{ijk}}$

Where;

$\mathrm{Y}_{\mathrm{ijk}}=$ measurement of trait on the $\mathrm{i}^{\text {th }}$ line of the $\mathrm{j}^{\text {th }}$ egg size of the $\mathrm{k}^{\text {th }}$ random error; $\mu=$ overall mean; $L_{i}=$ effect of the $i_{\text {th }}$ line (sire and dam), $S_{j}=$ effect of the $j^{\text {th }}$ egg size (small, medium and large) and $\mathrm{e}_{\mathrm{ijk}}=$ random error assumed to be normally and independently distributed.

Statistical analysis

All the data obtained were subjected to analysis of variance in a complete randomized design using SAS (2002). Significant means were separated using Duncan Multiple Range Test (Duncan, 1955).

\section{Results and Discussion}

Table 1 shows the effect of egg size on weight and weight loss during incubation. Significant differences $(p<0.05)$ were recorded in egg size with values of small $(46.46 \pm 1.10)$, medium $(55.90 \pm 1.09)$ and large (64.14 \pm 1.17$)$, respectively. Egg weight loss (\%) after 18 days in incubation had significant $(\mathrm{p}<0.05)$ differences with minimum loss in the large egg $(10.85 \pm 0.09)$ size group while small $(11.01 \pm 0.12)$ and medium (11.05 \pm 0.07$)$ egg size were similar. The result obtained in this study on egg weights is comparable with those of Javid et al. (2016) where they obtained egg weights of $60.05 \mathrm{~g}$ (small), $65.03 \mathrm{~g}$ (medium) and 70.03 (large) in Hubbard Classic broiler breed. However, Abiola et al. (2008) reported values of $41.09-50.97 \mathrm{~g}$ (small), 50.98 - 57.98g (medium) and 57.40 - 69.64g (large) in Anak broiler which are similar with the findings of this present study. Although the values are comparable, the possible differences could be attributed to breed difference, age of the parent hen and degree of selection on the birds. The finding on egg weight loss had the small size eggs lost more weight than medium and large and is similar with those of Javid et al. (2016) where they obtained between $10.62-11.32 \%$ weight losses at $18^{\text {th }}$ day for similar egg size in Hubbard Classic broiler breed with more loss recorded against the small size eggs. Also, Ulmer-Franco et al. (2010) reported that the percentage of egg weight loss decreased as egg size increased in Cobb 500 broiler breeder hen. Also, weight loss of between 10.85 to $11.05 \%$ obtained in the present study is in variance and do not support the results of Hristakieva et al. (2014) who obtained 15.91\% for Ross 308 broiler and $14.74 \%$ for Cobb 500 broilers.

Javid et al. (2016) suggested that owing to the increased surface-to-volume ratio in small eggs (inferred from egg size); it was not surprising to observe that the small eggs lost the highest percentage of moisture. Large eggs had a greater proportion of albumen (and thus greater moisture content) than small eggs. Similarly, the average weight loss of $10.97 \%$ regardless of the egg size class in the study is lower than the value of $12.94 \%$ reported by Soliman et al. (1994) for quail eggs but higher than $7.75 \%$ reported by Javid et al. (2016) in Hubbard Classic broiler. It is also lower than the values of $24.76 \%$ reported by Saylam (1999) and 20.90\% reported by Saylam and Sarica (1999) in quail eggs, and higher than the values of $1.25 \%$ reported by Khan et al. (2013) in Fayoumi eggs which consequently affect the chick weight at hatching. The differences in weight losses among different studies during incubation can be due to the difference in species. Egg 


\section{Effect of egg size and lines on hatching performance of chicks from broiler breeders under selection}

weight loss that occurs during incubation of eggs is about utterly due to water diffusion through the shell (Tona et al. 2001). Incubation egg weight losses are a function of egg characteristics (shell structure, membrane structure and initial egg weight) and interacting incubation conditions (temperature, humidity and air velocity) under which the eggs were set (Gonzalez et al. 1999). Similarly, Deeming (1995) determined that $10-12 \%$ weight loss is necessary during incubation in order to get a good incubation result in stored and nonstored eggs.

Table 1: Effect of egg size on egg weight and weight loss during incubation

\begin{tabular}{lcc}
\hline Egg size & Egg weight at time of incubation (g) & Egg weight loss (\%) at 18day in incubation \\
\hline Small & $46.46 \pm 1.10^{\mathrm{c}}$ & $11.05 \pm 0.07^{\mathrm{b}}$ \\
Medium & $55.90 \pm 1.09^{\mathrm{b}}$ & $11.01 \pm 0.12^{\mathrm{b}}$ \\
Large & $64.14 \pm 1.17^{\mathrm{a}}$ & $10.85 \pm 0.09^{\mathrm{a}}$ \\
P-value & 0.032 & 0.04 \\
\hline
\end{tabular}

$\overline{\mathrm{abc}}=$ Means in the same column with different superscripts are statistically different $(\mathrm{P}<0.05)$

Table 2 shows the LSM effect of egg size on hatch weight with significant differences $(\mathrm{p}<0.05)$ obtained between the egg sizes. The result revealed that hatch weight was amplified as the egg size increased as this correlates the earlier reports of Javid et al. (2016) in Hubbard classic broiler that increase egg size increases the hatch weight and chick length however, the chick weight obtained by the authors were (40.29$47.82 \mathrm{~g}$ ) much heavier than the 36.24 to $40.22 \mathrm{~g}$ obtained in this study. Also, Olutunmogun et al. (2016), obtained similar hatch weight of between 37.52 to $37.73 \mathrm{~g}$ in two lines of broiler parent under selection though the authors did not group the hatching eggs into egg size group.
These differences in chick weight could be tailored to degree of select, environment factors (quality of feed, weather) and age/potential of parent breeder. Adeyinka et al. (2001) observed that the setting size of hatching eggs on the chicks' performance at day old and at subsequent ages is affected by egg size with the larger egg size having a higher chick quality over other egg sizes in two strains of Rhode Island Red. Chick or hatch weight as reported by Decuypere et al. (2002) is the most widely used indicator for day-old chick quality assessment. It is known that a positive correlation exists between egg size and chick weight in broiler chickens (Abiola et al. 2008).

Table 2: Least square means effect of egg size on hatch weight

\begin{tabular}{lc}
\hline Egg size & Hatch weight (g) \\
\hline $\begin{array}{l}\text { Small } \\
\text { Medium }\end{array}$ & $36.24 \pm 0.91^{\mathrm{b}}$ \\
Large & $36.73 \pm 0.80^{\mathrm{b}}$ \\
P-value & $40.22 \pm 0.61^{\mathrm{a}}$ \\
ab= Means in the same column with different superscripts are statistically different $(\mathrm{P}<0.05)$
\end{tabular}


between $33.95 \mathrm{~g}, 36.70 \mathrm{~g}$ and $41.94 \mathrm{~g}$ hatch weights for similar egg size and also obtained $38.26 \mathrm{~g}$ and $37.13 \mathrm{~g}$ for Dominant Black and Yaffa Brown strains.

Table 3: Least square means effect of line on egg weight and hatch weight

\begin{tabular}{|c|c|c|c|}
\hline \multirow{2}{*}{$\begin{array}{l}\text { Traits } \\
\text { Egg size }\end{array}$} & \multicolumn{2}{|c|}{ Line/egg weight (g) } & \multirow[b]{2}{*}{ P-value } \\
\hline & Sire & Dam & \\
\hline Small & $47.37 \pm 1.13^{\mathrm{ns}}$ & $48.00 \pm 1.32^{\mathrm{ns}}$ & 0.199 \\
\hline Medium & $57.50 \pm 0.44^{\mathrm{a}}$ & $55.00 \pm 0.52^{\mathrm{b}}$ & 0.034 \\
\hline Large & $64.05 \pm 0.59^{\mathrm{ns}}$ & $64.25 \pm 0.61^{\mathrm{ns}}$ & 0.860 \\
\hline \multicolumn{4}{|c|}{ Line/hatch weight (g) } \\
\hline Egg size & Sire & Dam & P-value \\
\hline Small & $38.43 \pm 0.61^{\mathrm{ns}}$ & $37.52 \pm 0.80^{\mathrm{ns}}$ & 0.711 \\
\hline Medium & $39.71 \pm 0.33^{\mathrm{a}}$ & $36.10 \pm 0.29^{b}$ & 0.051 \\
\hline Large & $41.21 \pm 0.19^{\mathrm{ns}}$ & $41.27 \pm 0.28^{\mathrm{ns}}$ & 0.420 \\
\hline
\end{tabular}

The effect of egg size on the average egg weight, fertility, hatchability, embryonic mortality and infertile egg are as show in table 4. At this stage of production, all the parameters had significant $(\mathrm{p}<0.05)$ difference with the small egg size being superior in all the traits apart from average egg weight followed by the medium and lager egg sizes respectively. Fertility and hatchability are two major parameters that influence day-old chicks Javid et al. (2016). However, there is a scarcity of information on the effect of egg size on hatchability in broiler breeders of any breed. This result confirms the earlier report of Javid et al. (2016) for the small and medium egg size. Also, this result is in consonance with earlier observations of Kirk et al. (1980) that found that fertility of broiler breeders declined by $11 \%$ and hatchability declined $9 \%$ in eggs weighing more than $70 \mathrm{~g}$. In general, several authors agrees that it is preferable to have eggs of average weight to achieve good hatchability as far as chicken, turkey, ducks and ostriches are concerned (Brah et al., 1999; Gonzales et al., 1999). Actually, hatchability of the incubated eggs increased as egg weight increased to large egg-size group. Wilson (1991) suggested that egg size group of 60-69 g were best suited for incubation. Similar the results obtained in the current study suggest that best fertility and hatchability traits were obtained in small and medium egg size groups having 46.46-64.14g g egg weight. Reviews from literature shows that hatchability reduction of eggs from older broiler breeders is a result of many contributing factors, including larger egg size (Leeson and Summers 2000), increased early and late embryo mortality (Elibol and Braket 2003), poorer shell quality due to bigger surface area (Bennett 1992), albumen quality deterioration (Tona et al. 2004) and increased the yolk cholesterol content (Dikmen and Sahan 2007).

Table 4: Effect of egg size on fertility and hatchability performance

\begin{tabular}{lcccc}
\hline & \multicolumn{4}{c}{ Egg size } \\
\hline Parameters & Small & Medium & Large & P-value \\
\cline { 2 - 4 } Egg numbers & 50 & 50 & 50 & - \\
Av. egg weight (g) & $46.46 \pm 1.10^{\mathrm{c}}$ & $55.90 \pm 1.09^{\mathrm{b}}$ & $64.14 \pm 1.17^{\mathrm{a}}$ & 0.04 \\
Egg Fertility (\%) & $94.02 \pm 0.70^{\mathrm{a}}$ & $93.01 \pm 0.41^{\mathrm{a}}$ & $78.01 \pm 0.39^{\mathrm{b}}$ & 0.001 \\
Hatchability (\%) & $87.42 \pm 1.08^{\mathrm{a}}$ & $88.20 \pm 0.33^{\mathrm{a}}$ & $62.41 \pm 0.75^{\mathrm{b}}$ & 0.001 \\
Embryonic mortality (\%) & $6.58 \pm 0.39^{\mathrm{a}}$ & $9.80 \pm 0.11^{\mathrm{b}}$ & $15.6 \pm 0.20^{\mathrm{c}}$ & 0.003 \\
Infertile eggs (\%) & $6.01 \pm 0.70^{\mathrm{a}}$ & $7.00 \pm 0.41^{\mathrm{b}}$ & $22.00 \pm 0.39^{\mathrm{c}}$ & 0.001 \\
\hline abc & &
\end{tabular}

$\overline{\mathrm{abc}}=$ Means in the same row with different superscripts are statistically different $(\mathrm{P}<0.05)$, Av. $=$ Average 


\section{Conclusion}

In conclusion, minimum egg weight loss occurred in the large egg size group. To attain better fertility and hatchability traits in broiler breeder flock, medium egg size (52-61g) should be selected for incubation although the small egg size (greater than $46.46 \mathrm{~g}$ ) can also be considered. For larger chick at hatch, the large egg size can be used. Embryonic mortality (6.58 to $9.80 \%)$ and infertile eggs (6.01 to $7.00 \%$ ) were low for the small and medium egg size when compared to the 15.6 and $22.00 \%$ recorded for the large egg size.

\section{References}

Abanikannda, O. T. F., Leigh, A. O. and Giwa, A. O. 2011. Influence of egg weight, breed and age of hens on weight loss of hatching broiler eggs. Archiva Zootechnica, 14: 343-356.

Abiola, S. S. 1999. Effects of turning frequency of hen's egg in electric table-type incubator on weight losses, hatchability and mortality. Nigeria Agriculture Journal, 30: 77-82

Abiola, S. S., Meshioye, O. O., Oyerinde, B. O. and Bamgbose, M. A. 2008. Effect of egg size on hatchability of broiler chicks. Archivos de zootecnia, 57: 83-86.

Abudabos, A. 2010. The effect of broiler breeder strain and parent flock age on hatchability and fertile hatchability. International Journal of Poultry Science, 9: 231-235.

Adeyinka, I. A., Abubakar, B. Y., Oni, O. O. and Sekoni, A. A. 2001. Effect of egg size on chick hatch weight and subsequent body weights of two strains of Rhode Island chicks under selection. Tropical Journal of Animal Science, 4(2): 7-12.
Bennett, C. D. 1992. The influence of shell thickness on hatchability in commercial broiler breeder flocks. Journal of Apply Poultry Research, 1: 61-65.

Brah, G. S., Chaudhary, M. L. and Sandhu, J. S. 1999. Analysis of relation of egg weight with embryonic mortality, hatching time, chick weight and embryonic efficiency in chickens. Indian Journal of Poultry Science, 34: 308 -312 .

Decuypere, E., Tona, K., Bamelis F., Careghi, C., Kemps, B., De Ketelaere, B., De Baerdemaker, J. and Bruggeman, V. 2002. Broiler breeders and egg factors interacting with incubation conditions for optimal hatchability and chick quality. Archive fur Geflugelkunde, 66:56-57.

Deeming, D. C. 1995. What is chick quality? World's Poultry Science Journal, 11:20-23.

Deeming, D. C. 1995. Factors affecting hatchability during commercial incubation of ostrich (Struthio camelus) eggs. British Poultry Science, 36: 51-65.

Dikmen, B. Y. and Sahan, U. 2007. Correlations between breeder age, egg cholesterol content, blood cholesterol level and hatchability of broiler breeders. British Poultry Science, 48: 98-103.

Donald, D., Bell William, D. and Weaver, J. R. 2002. Commercial meat and egg production. $5^{\text {th }}$ edition, UK, Page 709-783.

Duncan, D. B. 1955. Multiple range and multiple F tests. Biometrics, 11: 142.

Egbeyale, L. T., Abiola, S. S., Sogunle, O. M. and Ozoje, M. O. 2011. Effect 
of egg size and strain on growth performance of cockerel. Agriculture and Biology Journal of North America, 2(12): 1445-1453.

Elibol, O. and Braket, J. 2003. Effect of frequency of turning from three to eleven days of incubation on hatchability of broiler hatching eggs. Poultry Science, 82: 357-359.

El-Safty, S. A. 2012. Influence of genotype and age of egg-type breeders on some hatching traits. Egyptian Poultry Science, 32:711-724.

Gonzalez, A., Satterlee, D. G., Moharer, F. Cadd, G. G. 1999. Factors affecting ostrich egg hatchability. Poultry Science, 78: 1257-1262.

Hristakieva, P., Mincheva, N., Oblakova, M., Lalev, M. and Ivanova, I. 2014. Effect of genotype on production traits in broiler chickens. Slovak Journal Animal Science, 47(1): 19-24

Javid, I., Sohail, H. K., Nasir, M., Tanveer, A. and Riaz, A. P. 2016. Effects of egg size (weight) and age on hatching performance and chick quality of broiler breeder. Journal of Applied Animal Research, 44(1): 54-64.

Kabir, M., Oni, O. O., Akpa, G. N. and Adeyinka, I. A. 2006. Heritability estimates and interrelationships of body weights and shank lengths in Rhode Island Red and White chickens. Pakistan Journal of Biological Sciences, 9(15): $2892-$ 2896.

Kalita, N. 1994. Effect of egg weight, storage period and position of egg on hatchability. Indian Poultry Science, 29(3): 281-283.

Khan, M. J. A., Khan, S. H., Bukhsh, A.,
Abbass, M. I. and Javed, M. 2013. Effect of different storage period on egg weight, internal egg quality and hatchability characteristics of Fayumi eggs. Italian Journal of Animal Science, 12(51): 323-328.

Khurshid, A., Farooq, M., Durrani, F.R., Sarbiland, K. and Chand, N. 2003. Predicting egg weight, shell weight, shell thickness and hatching chick weight of Japanese quails using various egg traits as regressors. International Journal Poultry Science, 2(2): 164-167.

King'ori, A. M., Tuitoek, J. K., Muiruri, H. K. and Wachira, A. M. 2007. Protein requirements of growing indigenous chickens during the 1421 weeks growing period. South African Journal of Animal Science, 33: 78-81.

King'ori, A. M. 2011. Review of the factors that influence egg fertility and hatchability in poultry. Indian Journal of Poultry Science, 10: 483-492.

Kirk, S., Emmans, G. C., Mcdonald, R. and Arnot, D. 1980. Factors affecting the hatchability of eggs from broiler breeders. British Poultry Science, 21:37-53.

Leeson, S. and Summers, J. D. 2000. Broiler breeder production. Guelph: University Books.

Olutunmogun, A. K., Umar, A. U., Adeyinka, I. A., Adejoh-Ubani, E. O., Nwagu, B. I., Abdulahi, I., Abeke, F. O., Sekoni, A. A., Ibrahim, M. A., Otu, M. O. and Haruna, H. M. 2016. Fertility, body weight and survivability of two lines of broiler stock under selection. Nigerian Journal of Animal Production, 43(2): 19-27.

Ovimaps, 2014. Ovilocation map; Google 
earth imaginary.

SAS. 2002. Statistical Analysis System, Computer Software, Version 9: Statistics SAS Institute Inc. Cary, NC 27513, NC 27513, USA.

Saylam, S. K. and Sarıca, M. 1999. Effects of shell thickness, shell pores and egg weight loss on hatchability on Japanese quail eggs. Turkish Journal of Veterinary and Animal Science, 23:41-46.

Soliman, F. N. K., Rizk, R. E. and Brake, J. 1994. Relationship between shell porosity, shell thickness, egg weight loss, and embryonic development in Japanese quail eggs. Poultry Science, 73: 1607-1611.

Wilson, H. R. 1991. Inter-relationship of egg size, chick size, post-hatching growth and hatchability. Journal of World's Poultry Science, 47: 5-20.

Rashid, M. M., Islam, M. N., Roy, B. C., Jakobsen, $K$. and Lauridsen, $C$. 2005. Nutrient concentrations of crop and gizzard contents of indigenous scavenging chickens under rural conditions of Bangladesh. Livestock Research for Rural Development, 17(2): 122-132.
Tona, K., Bamelis, F., Couke, W., Bruggeman, V. and Decuypere, E. 2001. Relationship between broiler breeders age and egg weight loss and embryonic mortality during incubation in large scale conditions. Journal of Applied Poultry Research, 10: 221-227.

Tona, K., Onagbesan, O., De Ketelaere, B., Decuypere, E. and Bruggeman, V. 2004. Effects of age of broiler breeders and egg storage on egg quality, hatchability, chick quality, chick weight and chick post hatch growth to forty-two days. Journal of Apply Poultry Research, 13: 10-18.

Tufft, L. S. and Jensen, L. S. 1991. Effect of age of hen, egg weight and sex on chick performance and lipid retention. Poultry Science, 70: 2411-2418.

Uluocak, A. N., Okan, F., Efe, E. and Nacar, H. 1995. Exterior and interior quality characteristics and their variation according to age in Japanese quail. Turkish Journal of Veterinary and Animal Science, 19: 181-187.

Received:12 $2^{\text {th }}$ November, 2017 Accepted: 12 $2^{\text {th }}$ February, 2018 